\title{
Late Quaternary Protoperidinium cysts as indicators of paleoproductivity in the northern Arabian Sea
}

\author{
Gert-Jan Reichart ${ }^{\mathrm{a}, \mathrm{b}, *}$, Henk Brinkhuis ${ }^{\mathrm{c}}$ \\ a Alfred Wegener Institute, Am Handelshafen 12, D-27570 Bremerhaven, Germany \\ b Geochemistry Department, Faculty of Earth Sciences, Utrecht University, Budapestlaan 4, 3584 CD Utrecht, The Netherlands \\ c Laboratory of Palaeobotany and Palynology, Utrecht University, Budapestlaan 4, 3584 CD Utrecht, The Netherlands
}

Received 29 July 2002; received in revised form 5 March 2003; accepted 12 March 2003

\begin{abstract}
The reliability of organic-walled cysts of the heterotrophic dinoflagellate Protoperidinium as paleoproductivity indicators and the influence of bottom water oxygenation on cyst preservation is assessed by using Arabian Sea records of the past $\sim 125 \mathrm{kyr}$ as a natural laboratory. Multidisciplinary geochemical, micropaleontological and palynological datasets are integrated to analyze the relationship between Protoperidinium cyst concentrations and other paleoproductivity proxies. Differential preservation potential is quantified in order to establish threshold oxidative degradation values for a possible application of quantitative Protoperidinium cyst records in paleoenvironmental reconstructions. Results indicate that variations in Protoperidinium cyst concentration closely correspond to other marine productivity and/or upwelling proxies. Although oxygenation will lead to significant cyst degradation, and thus decreased concentrations, down-core patterns in Protoperidinium cyst concentration still primarily reflect changes in sea surface productivity. In view of differential preservation among dinoflagellate cysts, down-core variations in relative abundance of Protoperidinium should be treated with caution.
\end{abstract}

(C) 2003 Elsevier B.V. All rights reserved.

Keywords: organic-walled dinoflagellate cysts; Protoperidinium; planktonic foraminifera; geochemistry; Arabian Sea; marine productivity

\section{Introduction}

Past efforts of applying organic-walled dinoflagellate cyst (dinocyst) analysis for reconstructing marine paleoproductivity have mainly focused on the relative and/or absolute numbers of cysts of Protoperidinium. Most species of Protoperidinium

\footnotetext{
* Corresponding author. Tel.: +49-(471)-4831-1689; Fax: +49-(471)-4831-1149.

E-mail address: greichart@awi-bremerhaven.de
} (G.-J. Reichart). are heterotrophic, usually feeding on diatoms. Although the potential of Protoperidinium cysts as marine eukaryotic productivity indicators is therefore evident (e.g. Dale and Fjellsa, 1993), dinocysts and other organic matter is degraded by bottom and pore water oxygen. Oxidation will ultimately change the relative species composition of a fossil assemblage as well as the absolute abundances, thus potentially obstructing accurate paleoenvironmental reconstructions. Indeed, there is evidence that not all dinocysts have the same preservation potential, with Proto- 
peridinium cysts being some of the first to be destroyed (Zonneveld et al., 1997, 2001; Versteegh and Zonneveld, 2002). Although the chemical composition of Protoperidinium cysts is unknown, the typically pale brown and smooth nature of the wall distinguish them from that of other dinoflagellate cysts, notably those of the gonyaulacoid lineage. This different appearance may be related to their apparent low resistance towards oxidation.

The Arabian Sea is characterized by high seasonal productivity and a strong mid-depth Oxygen Minimum Zone (OMZ) that both strongly influence sedimentation. The pronounced gradient in bottom water oxygen concentrations and cyclic sea surface productivity variations make this sea ideal for studying the effects of productivity and preservation on dinocysts. Moreover, pilot studies (unpublished results) indicated abundant dinocysts in piston cores spanning the past $\sim 125 \mathrm{kyr}$, that are overwhelmingly dominated by Protoperidinium cysts, mainly assignable to the cyst-based genus Brigantedinium.

In this paper, we investigate the reliability of Protoperidinium cysts as paleoproductivity indicators and the influence of bottom water oxygenation on cyst preservation. We have used multidisciplinary geochemical and micropaleontological datasets to: (1) analyze the relationship between Protoperidinium cyst concentrations and other paleoproductivity proxies, and (2) assess the effect of differential preservation to establish threshold degradation values for reliable quantitative Protoperidinium cyst-based paleoenvironmental reconstructions. For this purpose, we selected two sites from contrasting settings, viz. the Pakistan Margin (NIOP478) and the Oman Margin (NIOP497; Fig. 1). The sediments on the Oman Margin are from the summer monsoon-dominated, Oman upwelling area and were deposited under more or less continuously oxygenated conditions $(1750 \mathrm{~m}$ below sea surface (bss)). The Pakistan Margin sediments experienced periodical severe dysoxia under the influence of an intense OMZ, which strongly influenced organic matter preservation. In addition, we analyzed samples from the central part of the Arabian Basin from coeval intervals deposited under varying OMZ conditions.

\section{Climatic and oceanographic setting}

Surface water productivity in the northern Arabian Sea is strongly influenced by the semi-annual reversal in monsoonal winds. Heating of the Tibetan Plateau is at a maximum during the Northern Hemisphere summer, resulting in a strong pressure gradient between the Tibetan low-pressure cell and a high-pressure belt over the southern Indian Ocean. This pressure gradient generates warm and humid southwestern winds, causing coastal and open-ocean upwelling off Oman and Yemen. During the summer (southwest) monsoon surface water productivity rises to some of the highest values in the open ocean (Wyrtki, 1973; Smith and Bottero, 1977; Swallow, 1984; Brock et al., 1992). During the Boreal winter, cold northeastern winds blow from the high-pressure cell over Central Asia to the region of low pressure associated with the Inter-Tropical Convergence Zone at $\sim 10^{\circ} \mathrm{S}$. These winds cause onshore Ekman transport, which suppresses coastal upwelling and productivity (Slater and Kroopnick, 1984).

Annual high surface water productivity (between 200 and $400 \mathrm{gC} \mathrm{m}^{-2} \mathrm{yr}^{-1}$; Kabanova, 1968; Qasim, 1982; Codispoti, 1991) and moderate rates of thermocline ventilation (You and Tomczak, 1993), result in an intense OMZ between 150 and $1200 \mathrm{~m}$ (Wyrtki, 1973; Deuser et al., 1978; Olson et al., 1993). Oxygen concentrations in the OMZ drop to values $<0.05 \mathrm{ml} / 1$ (e.g.Van Bennekom and Hiehle, 1994). These low bottom water oxygen concentrations in the northern Arabian Sea have been shown to strongly affect biological, geochemical and sedimentological processes at the sediment-water interface (Schulz et al., 1996; Jannink et al., 1998; van der Weijden et al., 1999).

\section{Materials and methods}

Piston cores NIOP478 and NIOP497 were collected during the Netherlands Indian Ocean Program (1992-1993). NIOP478 was recovered from within the Pakistan Margin OMZ $\left(24^{\circ} 12^{\prime} .7 \mathrm{~N}\right.$, $065^{\circ} 39^{\prime} .7 \mathrm{E}$; water depth $565 \mathrm{~m}$; Fig. 1; Table 1). 


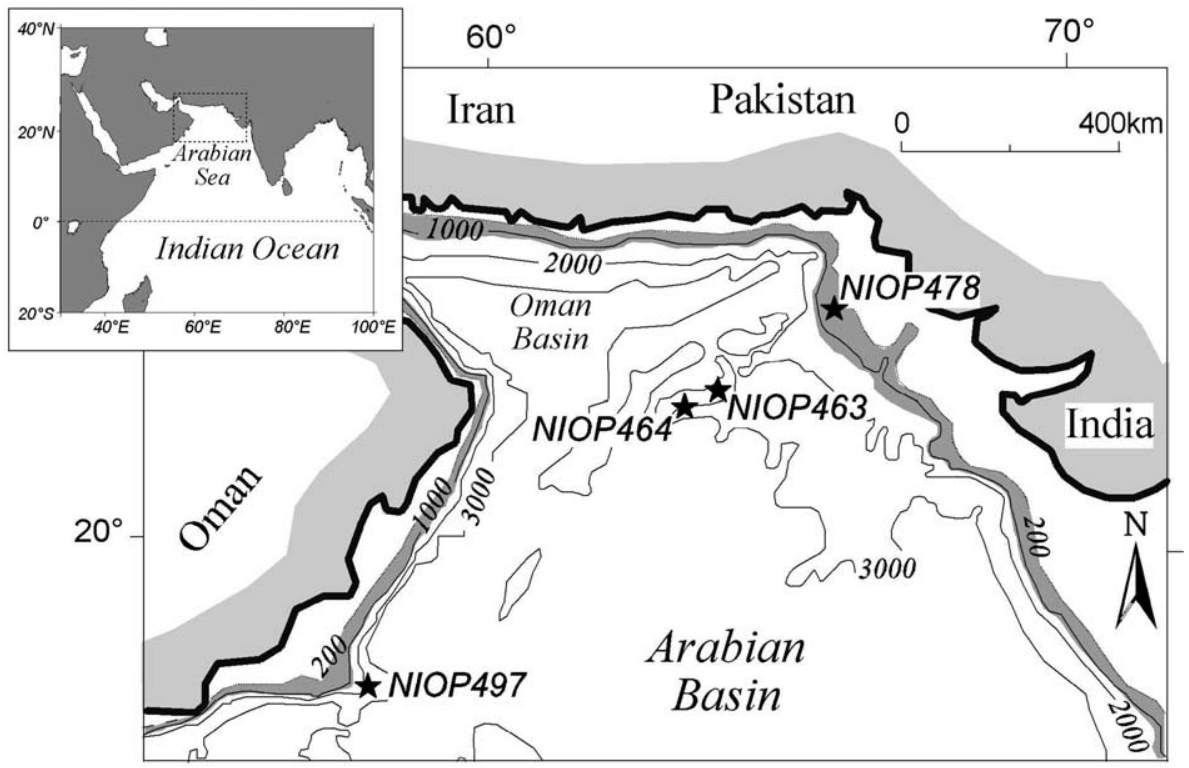

Fig. 1. Location map for piston cores NIOP463, NIOP464, NIOP478 and NIOP497. Cores NIOP463 and NIOP464 are located on a sub-marine high, the Murray Ridge. Gray area indicates where the OMZ (in the water column between 150 and $1200 \mathrm{~m}$ bss) intersects with the seafloor topography. Sites NIOP463 and NIOP478 are overlain by the present-day OMZ. Sites NIOP464 and NIOP497 are overlain by oxic bottom water.

Sediments from this site consist of homogeneous, dark greenish to light greenish/gray hemipelagic mud. Over a total length of $14.5 \mathrm{~m} \mathrm{NIOP478}$ has several laminated intervals. With the exception of a minor, possibly turbiditic layer at the base of the core, no turbiditic sediments were recognized. Samples were taken with a $20-\mathrm{cm}$ spacing, which results in a resolution of about $1 \mathrm{kyr}$ (see below; Fig. 2).

Core NIOP497 was recovered from the Oman Margin $\left(17^{\circ} 12^{\prime} .4 \mathrm{~N}, 057^{\circ} 57^{\prime} .6 \mathrm{E}\right.$; depth $1885 \mathrm{~m}$; Fig. 1; Table 1), well below the present-day OMZ. The sediments consist of homogeneous dark greenish to dark gray mud. The total length of NIOP 497 is $\sim 10 \mathrm{~m}$, but here we only consider the top $2 \mathrm{~m}$. The average sampling interval was 3 $4 \mathrm{~cm}$, which represents a $\sim 400$-yr interval (see below; Fig. 3). Core site NIOP 497 underlies the Oman Margin coastal upwelling area, where sea surface productivity is almost exclusively during the summer upwelling. In contrast, the sediments on the Pakistan Margin also receive a secondary organic matter flux related to increased winter productivity (Madhupratap et al., 1996). The dynamic sedimentary settings of the Oman and Yemen Margins have been shown to prevent high organic matter preservation (Pedersen et al., 1992). Sediments from the Pakistan Margin,

Table 1

Geographic positions of core stations with an indication of the current bottom water oxygenation

\begin{tabular}{lllll}
\hline Core & $\begin{array}{l}\text { Latitude } \\
(\mathrm{N})\end{array}$ & $\begin{array}{l}\text { Longitude } \\
(\mathrm{E})\end{array}$ & $\begin{array}{l}\text { Depth } \\
(\mathrm{m})\end{array}$ & Bottom water \\
\hline NIOP463 & $22^{\circ} 32^{\prime} .9$ & $064^{\circ} 02^{\prime} .8$ & 920 & dysoxic \\
NIOP464 & $22^{\circ} 15^{\prime} .4$ & $063^{\circ} 35^{\prime} .1$ & 1470 & oxic \\
NIOP478 & $24^{\circ} 12^{\prime} .7$ & $065^{\circ} 39^{\prime} .7$ & 565 & dysoxic \\
NIOP497 & $17^{\circ} 27^{\prime} .0$ & $057^{\circ} 57^{\prime} .6$ & 1885 & oxic \\
\hline
\end{tabular}




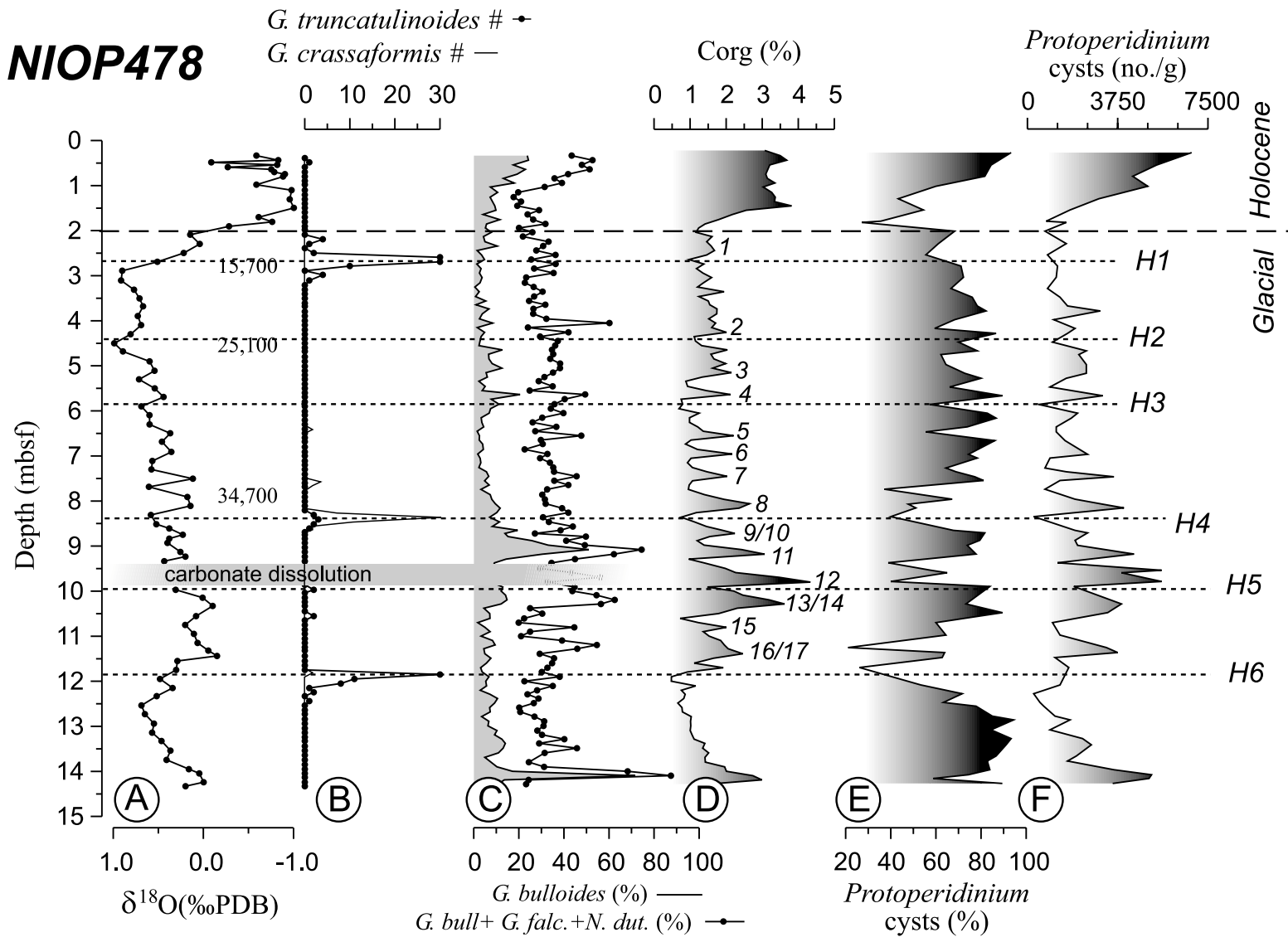

Fig. 2. Pakistan Margin core NIOP478 down-core records of oxygen isotopes (A), peak occurrences of the deep-dwelling foraminifera Globorotalia truncatulinoides and Globorotalia crassaformis (B), relative abundances of Globigerina bulloides and combined relative abundances of G. bulloides, Globigerina falconensis and Neogloboquadrina dutertrei (C). The organic carbon record (D) is plotted with numbers indicating correlative interstadials (Reichart et al., 1998; Schulz et al., 1998). Protoperidinium cysts are plotted both as relative abundance of the total dinocyst assemblage (E), and as numbers per gram (F). H1-H6 indicate correlation (Reichart et al., 1998, 2002a) to North Atlantic Heinrich cold events.

on the other hand, show lower organic matter degradation where the OMZ intersects the seafloor topography (van der Weijden et al., 1999).

In addition to the cores from the two contrasting margins we studied three sets of coeval samples from two cores, NIOP463 and NIOP464, from the central part of the Arabian Basin. Core NIOP463 is about $400 \mathrm{~m}$ below the top, and today in the OMZ; NIOP464 is from further down the flank of the ridge and is today below the OMZ (Fig. 1; Table 1). Sediments from these sites consist of dark greenish to light greenish/gray hemipelagic mud with cyclically varying $\mathrm{C}_{\text {org }}$ con- tent (Fig. 4). Present-day bottom water oxygen concentrations are $<0.05 \mathrm{ml} / 1$ for NIOP463 and ca. $0.9 \mathrm{ml} / 1$ for NIOP464. No pore water oxygen concentrations were measured, but the oxygen penetration depth is estimated to be $<0.1 \mathrm{~cm}$ for NIOP463. The reconstructed bioturbation depth and diagenetic manganese fronts indicate greater oxygen penetration at the deeper site (van der Weijden et al., 1999). Since both cores are located less than $50 \mathrm{~km}$ from each other and are physically separated from the Pakistan continental margin, fluxes from the productive sea surface layer can be considered to have been basi- 


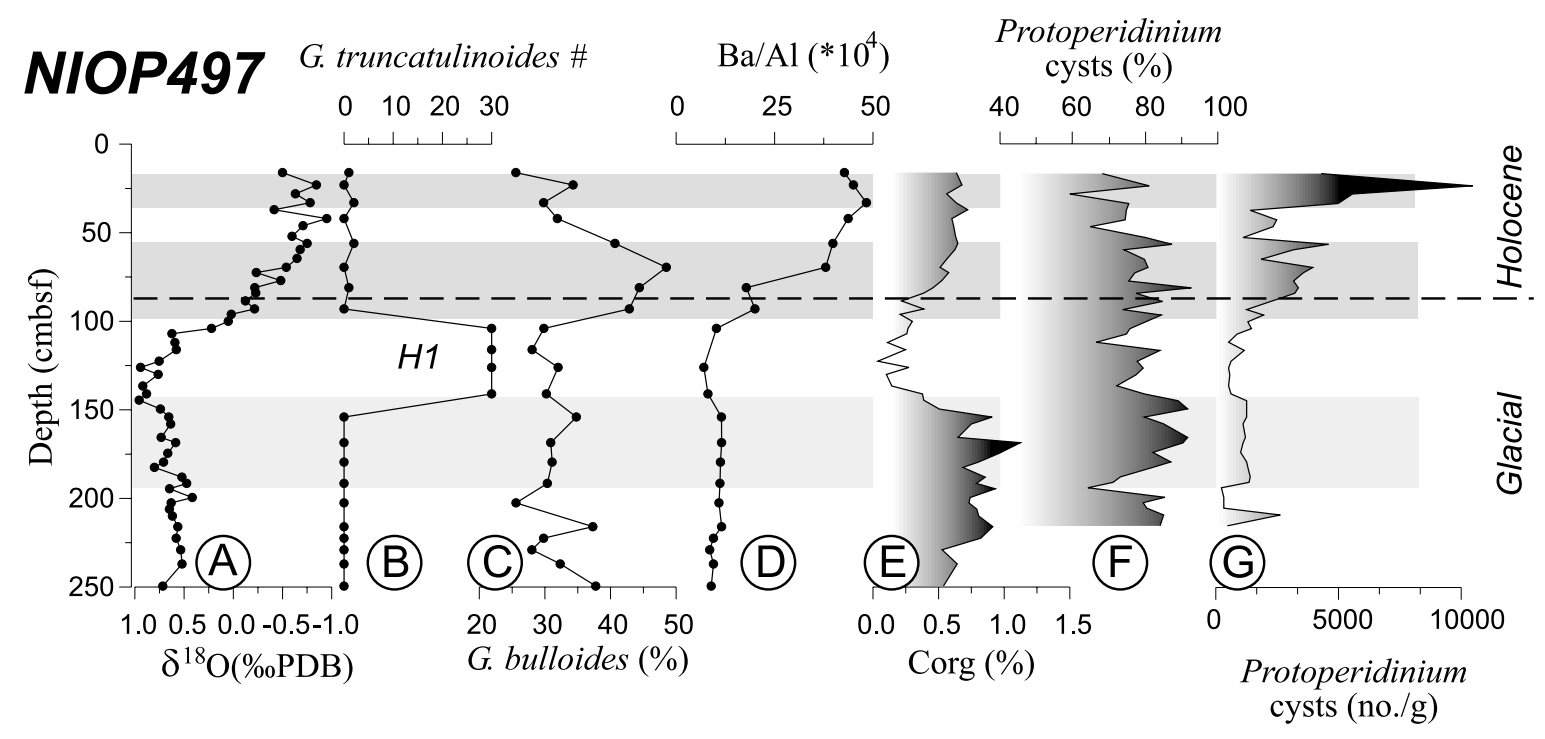

Fig. 3. For Oman Margin core NIOP497 oxygen isotope values for Neogloboquadrina dutertrei (A), peak occurrences of the deep dwelling foraminifer Globorotalia truncatulinoides (B), the relative abundances of the upwelling-associated foraminifer Globigerina bulloides (C), the Ba/Al ratio (D) and the organic carbon contents (E). Protoperidinium cysts are plotted both as relative abundances within the total dinocyst assemblage $(\mathrm{F})$ and as numbers per gram $(\mathrm{G})$. H1 refers to North Atlantic Heinrich event 1 and can be correlated directly to the H1 of Fig. 2 (Reichart et al., 2002a). The two gray bands highlight the two Holocene Protoperidinium cyst maxima

cally identical for the two sites. Three sets of samples (PP1-3) were taken from selected coeval intervals from each core (Table 2; see also below).

\subsection{Palynological sample processing}

Samples of approximately $2 \mathrm{~g}$ were oven-dried for $24 \mathrm{~h}$ at $60^{\circ} \mathrm{C}$. After weighing, samples were treated with $10 \% \mathrm{HCl}$ in order to remove carbonates. Following addition of demineralized water, the samples were left for $24 \mathrm{~h}$. The samples were neutralized by adding $10 \% \mathrm{KOH}$, and again left for $24 \mathrm{~h}$. After decanting 38\% $\mathrm{HF}$ was added to remove silicates. Then the samples were shaken for $2 \mathrm{~h}$ at about $250 \mathrm{rpm}$ and $24 \mathrm{~h}$ later neutralized with $30 \% \mathrm{KOH}$. Demineralized water was added. After another $24 \mathrm{~h}$ the samples were decanted and sieved 3 times with a Stork Veco Precision Sieve $(10 \mu \mathrm{m})$. The remaining material was kept in Eppendorf vials with $0.5 \mathrm{ml}$ of added demineralized water. Slides were made using $1 / 20$ of the material on microscope slides, embedded in glycerin jelly sealed with paraffin wax. Entire slides were counted with a minimum of

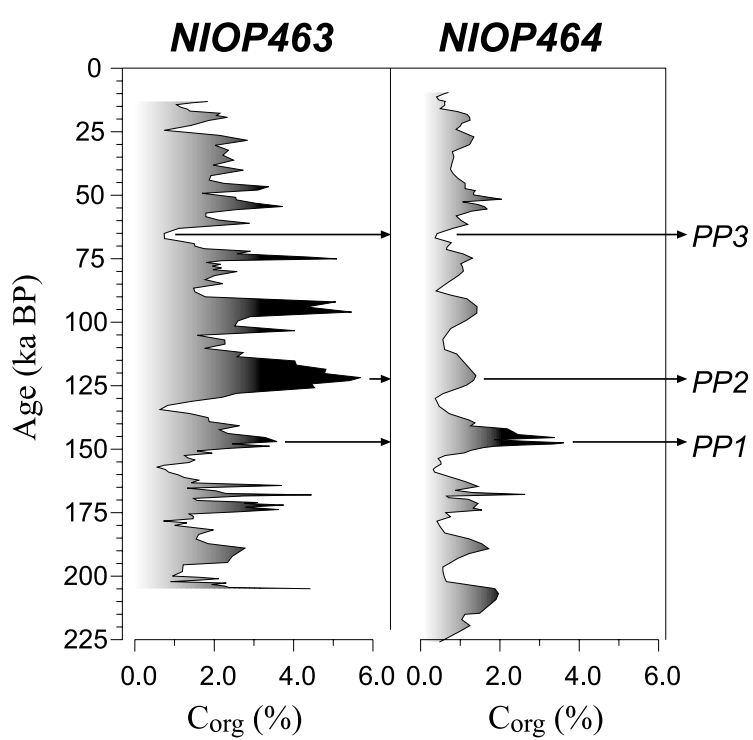

Fig. 4. The organic carbon records from the Murray Ridge sites NIOP463 and NIOP464 plotted vs. age (data from Reichart et al., 1998). Time slices sampled for dinocysts and pollen analyses PP1-PP3 are indicated with arrows. 
200 palynomorphs per sample. Palynomorph accumulation rates were calculated multiplying numbers/g with mass accumulation rates based on isotope stratigraphy and fixed volume samples (see also Sinninghe Damste et al., 2002).

The nomenclature applied in this study is based on that cited in Williams et al. (1998). For the purpose of the present paper, all cyst-based taxa related to motile Protoperidinium (cf. Head, 1996) have been grouped as Protoperidinium spp.

\subsection{Geochemical analyses}

We measured organic carbon content on a CNS analyzer (Fison NA 1500) after removal of carbonates. Carbonates were extracted using $1 \mathrm{M}$ $\mathrm{HCl}$ and shaking for $24 \mathrm{~h}$, subsequently samples were centrifuged for $15 \mathrm{~min}$ at $2800 \mathrm{rpm}$ and decanted. Then, again $1 \mathrm{M} \mathrm{HCl}$ was added, followed by shaking for $4 \mathrm{~h}$, and centrifuging for $15 \mathrm{~min}$. $\mathrm{CaCl}_{2}$ was removed by rinsing with demineralized water. We determined analytical precision and accuracy by replicate analyses of samples, and by comparison with an international standard (BCR-71), and in-house standards (F-TURB and MM-91). The relative standard deviations, analytical precision and accuracy were all better than $3 \%$.

For $\delta^{18} \mathrm{O}$ analysis 30 handpicked specimens of Neogloboquadrina dutertrei were roasted for $30 \mathrm{~min}$. at $380^{\circ} \mathrm{C}$ under vacuum to remove organic remains. Specimens were transferred to an automated carbonate preparation unit (IsoCarb), after which the isotopes were measured on a mass spectrometer (VG SIRA 24). Values are reported relative to Peedee Belemnite in standard $\delta$ notation; calibration is achieved through analysis of the National Bureau of Standards 19 reference materials. Precision for $\delta{ }^{18} \mathrm{O}$ measurements was better than $0.1 \%$ (see also Reichart et al., 1998).

We determined element concentrations for $\mathrm{Ba}$ and $\mathrm{Al}$ by inductively coupled plasma atomic emission spectrometry (Perkin Elmer Optima 3000). Part of the sample was dried at $60^{\circ} \mathrm{C}$ for 4 days, thoroughly ground in an agate mortar prior to $\mathrm{HClO}_{4}, \mathrm{HNO}_{3}$ and $\mathrm{HF}$ acid digestion, dried completely and finally was taken up in $1 \mathrm{M}$
HCl. Comparison with international (SO-1) and in-house (MM-91) standards and the analysis of duplicate samples revealed that the relative standard deviations, analytical precision and accuracy were better than 3\% (Reichart et al., 1998).

\subsection{Foraminiferal sample processing}

Planktonic foraminiferal counts were made on splits (using an Otto microsplitter) from the 150 $595 \mu \mathrm{m}$ fraction. 200-400 specimens per sample were picked, mounted on Chapman slides, identified and counted. Because the relative abundances of Globorotalia truncatulinoides and Globorotalia crassaformis are low $(<3 \%)$, these species were quantified separately by counting their numbers in 27 (of 45) fields of a rectangular picking tray to a maximum of 30 specimens (Reichart et al., 1998).

\subsection{Stratigraphy}

The chronology for the cores is mainly based on oxygen isotope stratigraphy. The time interval selected from NIOP497 for this study comprises the last glacial maximum until the early Holocene (Fig. 3). The oxygen isotope record shows that this part of the record corresponds to about the top $4 \mathrm{~m}$ of NIOP478 (Fig. 2A). This core was studied over its full length and comprises the uppermost part of stage 5 up to $14 \mathrm{~m}$ depth, stage 4 from 14 to $12 \mathrm{~m}$, stage 3 from 12 to $4 \mathrm{~m}$, the last glacial from 4 to about $2 \mathrm{~m}$, with the top $2 \mathrm{~m}$ deposited during the Holocene. For NIOP478 three AMS ${ }^{14} \mathrm{C}$ datings were performed on monospecific foraminiferal samples (Fig. 2A). These datings confirm the oxygen isotope stratigraphy. The characteristic $\mathrm{C}_{\text {org }}$ pattern in this part of the Arabian Sea can be used to fine-tune these correlations on a sub-Milankovitch timescale (Reichart et al., 1998). The high-frequency monsoonal changes responsible have been correlated to the interstadial/stadial climate events first recognized in the Greenland GRIP (Dansgaard et al., 1993) and GISP2 (Grootes et al., 1993) ice cores (Reichart et al., 1998; Schulz et al., 1998) (Fig. 2D). Correlation of sub-Milankovitch climatic variability on the Oman and Pakistan Margins has shown 
that the changes in these two areas were synchronous (Reichart et al., 2002b).

The correlation between NIOP463 and NIOP464 is based primarily on oxygen isotope stratigraphy. The age model for NIOP464, which has been described elsewhere in detail (Reichart et al., 1997, 1998), was used to refine the control in NIOP463. The resulting organic carbon vs. depth records for the two cores show a high correspondence on a precessional scale (Fig. 4). However, the magnitudes of the precession-related organic carbon maxima differ considerably. Since we limit our study to three horizons, this correlation suffices (see also Sinninghe Damste et al., 2002). Time slice PP1 corresponds to $66 \mathrm{ka}, \mathrm{PP} 2$ to $123 \mathrm{ka}$ and PP3 to 147 ka (Table 2; see also Reichart et al., 1998). Bottom water oxygenation was reconstructed for the two sites using redox sensitive trace metals and benthic foraminiferal faunal characteristics (Reichart et al., 1998; den Dulk et al., 2000). This reconstruction was subsequently used to select the three environmentally contrasting time slices (Table 2). During the first time slice (PP1) primary productivity was high, and a vertically expanded OMZ influenced sedimentation at both sites. The second time slice (PP2), although characterized by increased productivity, had an OMZ similar to that of today. Sediments at NIOP463 were deposited under dysoxia, whereas bottom waters at site 464 were oxygenated. The third time slice (PP3) was characterized by low sea surface productivity, thus low fluxes of organic matter and a weak or absent OMZ.

\section{Results}

On both the Pakistan and Oman Margins dinocyst assemblages are generally dominated by Brigantedinium spp. Other cysts associated with the motile Protoperidinium (cf. Head, 1996), such as (cyst) representatives of e.g. Echinidinium, Stelladinium, Selenopemphix, Trinovantedinium, and Lejeunecysta, are subordinate to Brigantedinium in numbers by an order of magnitude. All these cysts are grouped here as Protoperidinium spp. (Figs. 2 and 3). Among gonyaulacoid (autotrophic) cysts, representatives of Spiniferites, Impagidinium, Nematosphaeropsis and Polysphaeridium are only occasionally common in isolated samples (compare Reichart et al., submitted).

In both Pakistan Margin core NIOP478 and Oman Margin core NIOP497, high concentrations of Protoperidinium cysts can be seen to co-vary with upwelling/paleoproductivity indicators in general $\left(\mathrm{C}_{\text {org }}\right.$, Globigerina bulloides $\%, \mathrm{Ba} / \mathrm{Al}$; Figs. 2 and 3). On the Pakistan Margin (NIOP478), the highest absolute and relative Protoperidinium cyst abundances are recorded from the Holocene (Fig. 2E,F). This coincides with a higher organic carbon content of the sediment and increased relative abundances of planktonic foraminiferal species G. bulloides (Fig. 2C) which is an indicator of upwelling. The Holocene also shows higher relative abundances of the planktonic foraminiferal species Globigerina falconensis, which has been associated with sea surface productivity in the northern Arabian Sea in response

Table 2

Selected sample horizons from Murray Ridge cores NIOP464 and NIOP463

\begin{tabular}{|c|c|c|c|c|c|}
\hline Sample & $\begin{array}{l}\text { Depth } \\
\text { (cm) }\end{array}$ & $\begin{array}{l}\text { Age } \\
\text { (ka) }\end{array}$ & Core & Bottom water & Productivity \\
\hline \multirow[t]{2}{*}{ PP1 } & 912 & 147 & NIOP463 & dysoxic & high \\
\hline & 975 & 147 & NIOP464 & dysoxic & high \\
\hline \multirow[t]{2}{*}{ PP2 } & 760 & 123 & NIOP463 & dysoxic & high \\
\hline & 805 & 123 & NIOP464 & oxic & high \\
\hline \multirow[t]{2}{*}{ PP3 } & 353 & 66 & NIOP463 & oxic & low \\
\hline & 527 & 66 & NIOP464 & oxic & low \\
\hline
\end{tabular}

Depth in $\mathrm{cm}$ from the seafloor, age are in ka BP. Bottom water conditions and productivity refer to conditions during deposition. 


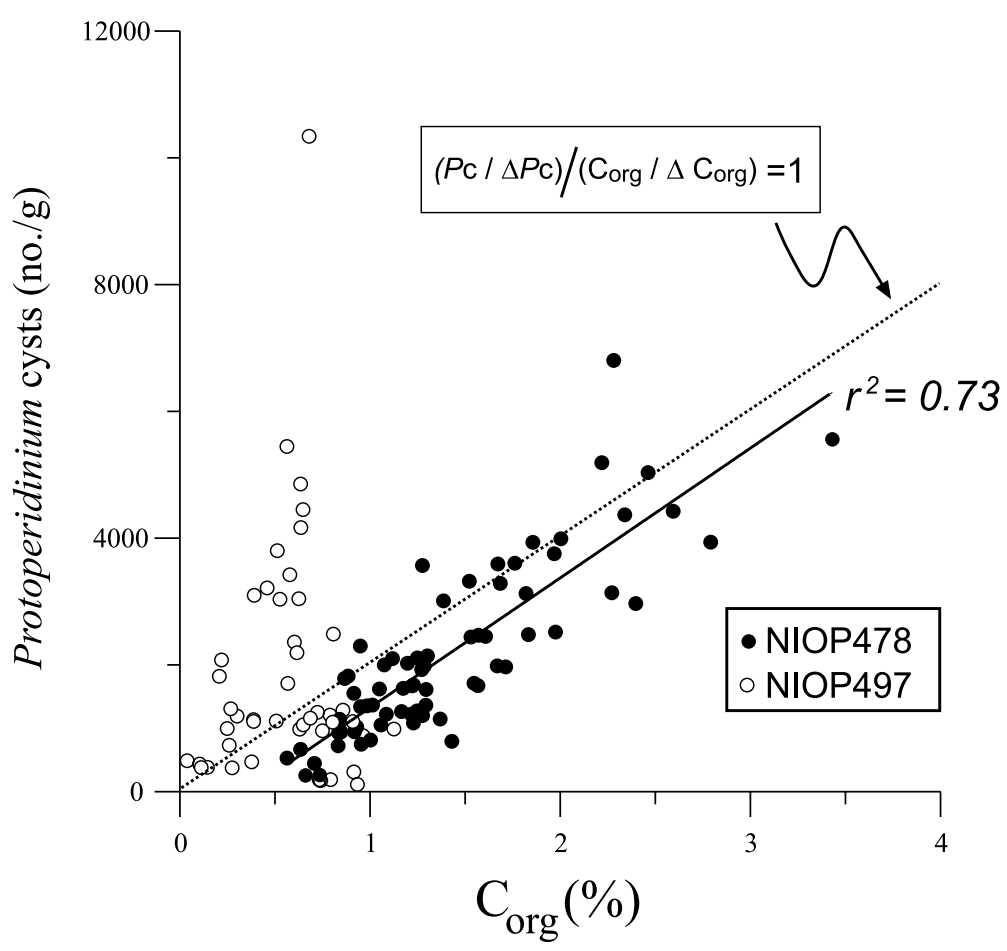

Fig. 5. Absolute abundances of Protoperidinium cysts, as numbers per gram, plotted against the organic carbon content (\%) for both Oman Margin core NIOP497 (open circles) and Pakistan Margin core NIOP478 (black circles). The correlation coefficient $\left(r^{2}\right)$ is for Pakistan Margin sediments only, no correlation is observed for the Oman Margin. Dashed line indicates hypothetical relation assuming similar decay rates for bulk organic matter and Protoperidinium cysts.

to winter mixing (den Dulk et al., 2000). In this part of the Arabian Sea a significant part of the annual productivity takes place during winter (Madhupratap et al., 1996). Further down-core in NIOP478 several other Protoperidinium maxima are recorded. These correspond to increased relative abundances of the foraminifer $G$. bulloides, or the combined abundance of Neogloboquadrina dutertrei, G. bulloides and G. falconensis, all of which are indicators for enhanced productivity or upwelling (Fairbanks and Wiebe, 1980; Fairbanks et al., 1982). Throughout Protoperidinium peaks correspond to higher $\mathrm{C}_{\text {org }}$ concentrations (Fig. 2D-F). The absolute abundance of Protoperidinium cysts correlates $\left(r^{2}=0.73\right)$ with the organic carbon content in core NIOP478 from the Pakistan Margin (Fig. 5). The relative abundance (\%) of Protoperidinium cysts, in contrast, correlates less well with $\mathrm{C}_{\text {org }}$ values (Fig. 2D,E), although the pattern remains the same.

In core NIOP497 on the Oman Margin abso- lute Protoperidinium abundances show a less obvious correlation with the relative abundance of Globigerina bulloides (Fig. 3). Globigerina falconensis and Neogloboquadrina dutertrei are not present in significant numbers, however, high $\mathrm{Ba} / \mathrm{Al}$ values match the curve of absolute Protoperidinium cyst abundances (Fig. 5). Sedimentary $\mathrm{Ba}$ is a frequently used indicator for paleoproductivity, also in the northern Arabian Sea (Shimmield et al., 1990; Reichart et al., 1997, 1998). Redistribution of $\mathrm{Ba}$, as a consequence of sulfate reduction (e.g. van Os et al., 1991) prevents the use of $\mathrm{Ba}$ as a paleoproductivity indicator at site NIOP478. On the Oman Margin, no positive correlation is apparent between $\mathrm{C}_{\text {org }}$ and Protoperidinium cysts/g (Fig. 3 and 5); the $\mathrm{C}_{\text {org }}$ record to some extent mimics the Protoperidinium cysts/g distribution in the upper part, not in the lower part of NIOP497. In both NIOP478 and NIOP497 Protoperidinium cysts/g minima are associated with peak occurrences of the planktonic 


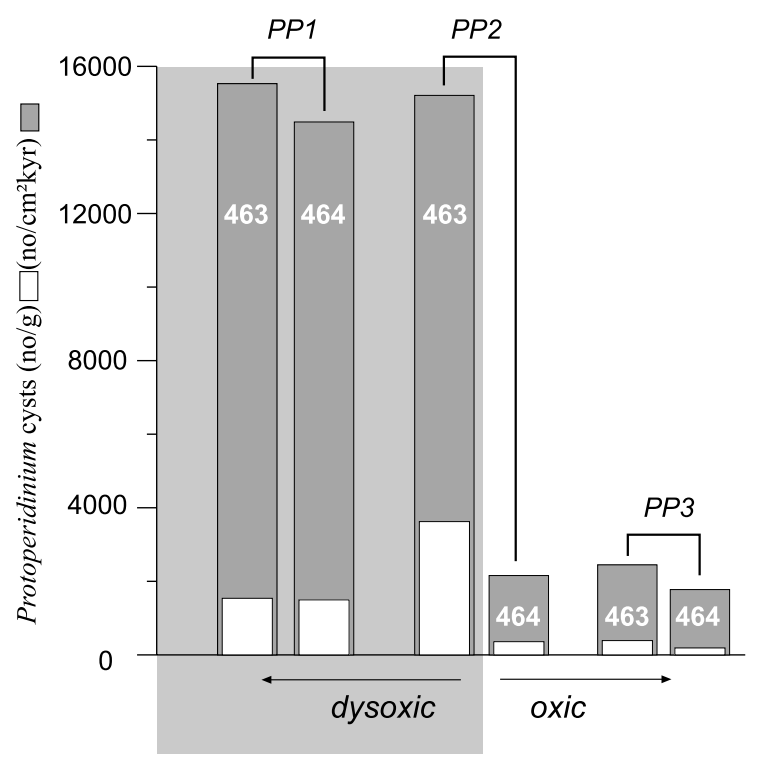

Fig. 6. Protoperidinium flux calculated for time slices PP1PP3 from Fig. 5. Dysoxic and oxic refer to conditions at the sediment-water interface during deposition.

foraminifer Globorotalia truncatulinoides (Figs. 2B and 3).

The accumulation rates of Protoperidinium cysts at sites NIOP463 and NIOP464 (Fig. 6) are comparable when both sites are inside the OMZ (time slice PP1). When the deeper site, NIOP464, was overlain by oxygenated bottom water, however, cyst accumulation rates were up to 10 times lower (time slice PP2). The accumu- lation rates for the time slice (PP3) characterized by a weak or absent $\mathrm{OMZ}$ at both sites are low (Fig. 6). We also calculated pollen accumulation rates for the NIOP463/464 samples (Table 3; other dinocysts are virtually absent in these samples). Taking preservation at the OMZ site NIOP463 as $100 \%$, differences in preservation potential between $\mathrm{C}_{\text {org }}$, pollen and Protoperidinium cysts can be calculated for NIOP464 (Table 3).

\section{Discussion}

\subsection{Protoperidinium cysts, primary productivity and upwelling}

The strong positive correlation between Protoperidinium cyst abundances and the $\mathrm{C}_{\text {org }}$ content of NIOP478, and productivity related planktonic foraminifera may be taken to indicate that concentrations of Protoperidinium reflect a (diatom) primary productivity signal. Low absolute Protoperidinium cyst abundances coincide with peak occurrences of the foraminifera G. trucatulinoides, which in the Arabian Sea is indicative of deep convective overturn (see Reichart et al., 1998). Low sea surface productivity and a well-oxygenated water column characterize these episodes of deep convective turnover. Changes in OMZ intensity coinciding with productivity variations (Reichart et al., 1998, 2002b; Schulz et al.,

Table 3

Sample numbers, fluxes of Protoperidinium cysts in no. $/ \mathrm{cm}^{2} \mathrm{kyr}$, pollen fluxes also in no. $/ \mathrm{cm}^{2} \mathrm{kyr}$, and organic carbon content

\begin{tabular}{|c|c|c|c|c|c|c|c|}
\hline Sample & $\begin{array}{l}\text { Protoperidinium } \\
\text { (no./g) }\end{array}$ & $\begin{array}{l}\text { Protoperidinium flux } \\
\left.\text { (no. } / \mathrm{cm}^{2} \mathrm{kyr}\right)\end{array}$ & $\begin{array}{l}P f \\
(\%)\end{array}$ & $\begin{array}{l}\text { Pollen flux } \\
\text { (no./ } / \mathrm{cm}^{2} \mathrm{kyr} \text { ) }\end{array}$ & $\begin{array}{l}P f \\
(\%)\end{array}$ & $\begin{array}{l}\mathrm{C}_{\mathrm{org}} \\
(\%)\end{array}$ & Scenario \\
\hline NIOP463/PP1 & 1538 & 15531 & 93 & 3414 & 78 & 3 & $\begin{array}{l}\text { High productivity } \\
\text { Expanded OMZ }\end{array}$ \\
\hline NIOP464/PP1 & 1493 & 14488 & & 2666 & & 3 & \\
\hline NIOP463/PP2 & 3621 & 15211 & 14 & 5047 & 9 & 5 & $\begin{array}{l}\text { High productivity } \\
\text { OMZ similar to } \\
\text { present }\end{array}$ \\
\hline NIOP464/PP2 & 359 & 2155 & & 458 & & 1.5 & \\
\hline NIOP463/PP3 & 388 & 2446 & 73 & 1031 & 123 & 1 & $\begin{array}{l}\text { Low productivity } \\
\text { Weak/absent OMZ }\end{array}$ \\
\hline NIOP464/PP3 & 187 & 1774 & & 1273 & & 1 & \\
\hline
\end{tabular}

The last column gives the depositional conditions. Expansion of the OMZ requires a deepening of its lower depth limit. The preservation factor $(P f)$ is discussed in the text. 
1998), must also have affected both overall sedimentary organic matter content and absolute Protoperidinium cyst abundances. The linear correlation between absolute cyst abundance and $\mathrm{C}_{\mathrm{org}}$, however, indicates that there has not been preferential degradation of Protoperidinium cysts compared to the bulk organic matter at least in the range of $\mathrm{C}_{\text {org }}$ values between 0.5 and $3.5 \%$ (Fig. 4). In NIOP497, it appears that oxygenation altered the original composition of the organic contents to a much larger extent. Overall organic matter concentrations here are much lower despite the fact that this core was recovered from the Oman upwelling area.

Globigerina bulloides in NIOP497, generally regarded as an upwelling indicator (Prell et al., 1980; Reichart et al., 1997), increases in abundance at the glacial-Holocene transition; this is also reflected in absolute Protoperidinium cyst abundance (Fig. 3). Increased relative abundances of $G$. bulloides thus indicate enhanced summer monsoon-driven upwelling during the Holocene, causing higher sea surface productivity. This is also reflected by higher $\mathrm{Ba} / \mathrm{Al}$ ratios. Although the absolute Protoperidinium cyst abundances confirm increased upwelling rates, $\mathrm{C}_{\text {org }}$ concentrations remain relatively low (Fig. 3). Since comparison of cyst fluxes at sites NIOP463 and NIOP464 showed a rapid cyst breakdown under oxic depositional conditions, actual fluxes of dinocysts, and also organic matter in general, at site NIOP497 must have been significantly higher. Nevertheless, trends in the absolute Protoperidinium cyst abundance record still reflect a primary productivity signal, as these match trends in the relative abundance of G. bulloides. It is apparent that the oxygenation selectively altered the organic matter content. Comparing absolute cyst abundances relative to organic carbon contents of NIOP478 and NIOP497 shows that NIOP497 is relatively enriched in Protoperidinium cysts. Apparently, the yet unknown wall chemistry of Protoperidinium cysts is more resistant to oxidation than most of the remaining organic matrix. This implies that until a certain level of oxic degradation is reached trends within the Protoperidinium cyst distribution continue to reflect changes in marine productivity.

\section{Preservation effects}

Relative preservation can be calculated for site NIOP464 relative to site NIOP463. This preservation factor $(P f)$ is defined as \{[Flux464]/ [Flux 463$]\} \times 100 \%$ (Table 2). This preservation factor thus gives the relative loss in pollen and Protoperidinium cysts for NIOP464 compared to NIOP463. Recently, Sinninghe Damste et al. (2002) have carried out a similar exercise for organic matter on the molecular level for the same sites and samples. Their results confirm that selective preservation is related to varying degrees of oxidation. Our results indicate that the preservation factor for Protoperidinium cysts and pollen grains is comparable. Whereas Protoperidinium preservation changes from 93 to $14 \%$ from an anoxic to an oxic setting (Table 3), pollen grains change from 78 to $9 \%$. Protoperidinium cysts are degraded seven times more readily in oxic sediment, the pollen eight times. Pollen grains can be regarded as ranking among the most resistant palynomorphs (Traverse, 1994), and hence these results suggest that differential preservation among palynomorphs, and notably dinocysts, may not be as straightforward as suggested by recent studies in other regions (see Versteegh and Zonneveld, 2002). Laboratory experiments on palynomorph degradation also show systematic offsets depending on the degree of oxidation (Hopkins and McCarthy, 2002). These experiments, however, show that whereas oxidation initially changes relative abundances towards certain taxa, prolonged exposure to an oxidant favors other taxa. Such a response to oxidation results in step-like changes in relative dinocyst abundances when exposed to oxidation, rather than a gradual decrease in specific taxa relative abundance.

Plotting the absolute Protoperidinium cyst abundances in northern Arabian Sea surface sediments (data from Zonneveld, 1996) vs. bottom water oxygen concentrations clearly shows very high values in the $\mathrm{OMZ}$ sediments, and a rapid decline with increasing bottom water oxygen concentration (Fig. 7, field I). The relative contribution of Protoperidinium cysts to the total dinocyst assemblage shows more scatter, but remains rela- 


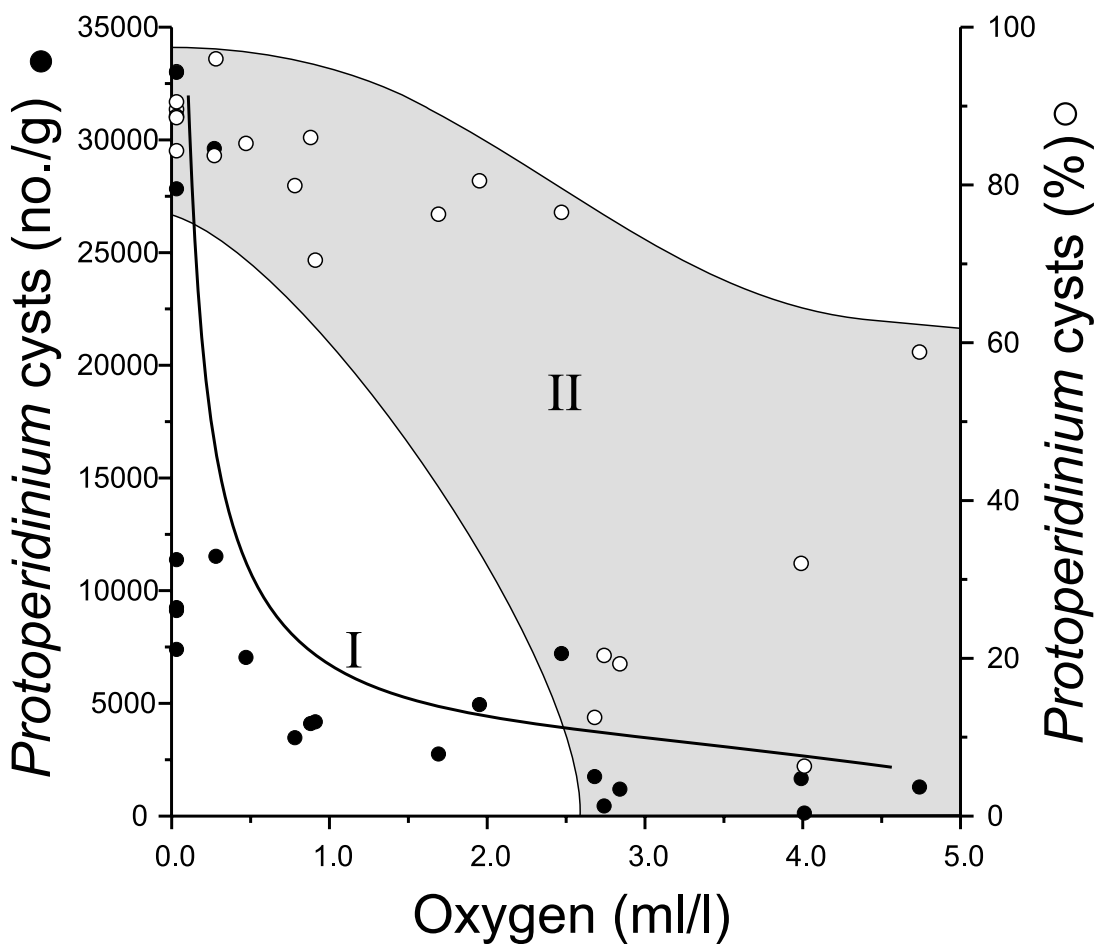

Fig. 7. Absolute (closed circles) and relative (open circles) Protoperidium cyst abundances of sediment surface samples plotted vs. oxygen concentration at the sediment-water interface for the Oman and Pakistan Margins. Dinocyst data are from Zonneveld (1996), data from the Makran part of the Pakistan Margin were omitted because of frequent turbidites and sediment reworking, oxygen data are from Netherlands Indian Ocean Programme (http://www.nioz.nl/en/facilities/dmg/niop/niop.htm). Trendline I indicates the fast decrease in absolute Protoperidinium cyst abundances with increasing bottom water oxygenation. Area II indicates the more general relation of relative Protoperidinium cyst abundances to bottom water oxygen concentrations.

tively constant at about $80 \%$ with bottom water oxygen concentration of less than $2.5 \mathrm{ml} / 1$. At higher bottom water oxygenation levels relative Protoperidinium abundances are lower, with a large scatter (Fig. 7, field II). The abrupt drop in relative Protoperidinium abundances at about $2.5 \mathrm{ml} / 1$ oxygen is in line with the step-like behavior suggested by the laboratory experiments (Hopkins and McCarthy, 2002).

Since cyst concentration in the sediment also depends on sedimentation rate, calculating absolute cyst abundance preservation demands that accumulation rates are used. Dinocyst accumulation rates for the top of the sediments, the socalled fluffy layer, can be calculated combining the dinocyst counts from Zonneveld (1996) with the ${ }^{14} \mathrm{C}$ data for the same boxes from van der Weijden et al. (1999). This suggests accumulation rates of close to 300000 Protoperidinium cysts/ $\mathrm{cm}^{2} \mathrm{kyr}$ within the $\mathrm{OMZ}$ on the Pakistan Margin (500 m bss; box core NIOP455 from Zonneveld, 1996; Van der Weijden et al., 1999). Although accumulation rates are evidently higher for the sites inside the $\mathrm{OMZ}$, such rates are much higher than calculated accumulation rates down-core (about 15000 cysts $/ \mathrm{cm}^{2} \mathrm{kyr}$ under anoxic conditions; Fig. 6). We surmise that the organic matter within the fluffy layer at the sediment surface is not yet in equilibrium since, even at the OMZ sites, about $70 \%$ of the organic matter arriving at the seafloor is degraded upon burial (van der Weijden et al., 1999). The organic matter at the top of the sediment may well consist mainly of material deposited within the last year. Furthermore, ongoing sedimentation will compact the sediment, making it difficult to compare rates for the topmost material with accumulation rates from further down-core. A more accurate ap- 
proach comes, therefore, from comparing accumulation rates of coeval samples from deeper in the sediment (Fig. 6). This shows that although significant (differential) dinocyst degradation takes place under oxic conditions, trends in Protoperidinium cysts/g and often also relative abundance patterns remain reliable indicators for ancient upwelling settings.

\section{Conclusions}

Using Protoperidinium cysts as indicators for past marine productivity in contrasting settings in the Arabian Sea we demonstrated that there is (1) a strong positive correlation between the absolute Protoperidinium cyst abundance and foraminiferal marine productivity and/or upwelling proxies, and that (2) different degrees of oxygenation lead to significant alteration in the fossil dinocyst assemblages. However, our study also demonstrates that the principal trends in the distribution of Protoperidinium cysts/g remain intact, even after severe and prolonged oxygen exposure and oxidation of most organic matter. Relative abundance trends are to be treated with more caution, since ongoing oxygenation and differential preservation will eventually cause a non-linear response in relative Protoperidinium abundance.

\section{Acknowledgements}

Thanks are due to F. Ammerlaan, G. van den Bos, F. Huiskamp, J. Targarona, and D. van den Akker for assisting with the data generation. J. van Tongeren and $\mathrm{N}$. Welters are thanked for processing the palynological samples. A. van Dijk, H. de Waard and G. Nobbe kindly assisted with the geochemical analysis. Stimulating discussions with G. Versteegh, K. Zonneveld and W.J. Zachariasse are gratefully acknowledged. Dr. J. Pross and Dr. G.L. Williams are thanked for their constructive reviews. This research was partly funded by the Netherlands Organization for Scientific Research. This is NSG contribution number 2003.03.05.

\section{References}

Brock, J.C., McClain, C.R., Anderson, D.M., Prell, W.L., Hay, W.W., 1992. Southwest monsoon circulation and environments of Recent planktonic foraminifera in the Northwestern Arabian Sea. Paleoceanography 7, 799-813.

Codispoti, L.A., 1991. Primary productivity and carbon and nitrogen cycling in the Arabian Sea. In: Smith, S.L., et al. (Eds.), U.S. JGOFS: Arabian Sea Process Study. U.S. JGOFS Planning Report, Woods Hole Oceanographic Institution, pp. 164.

Dale, B., Fjellsa, A., 1993. Dinoflagellate cysts as paleoproductivity indicators: State of the art, potential, and limits. In: Zahn, R., Pedersen, T.F., Kaminski, M.A., Labeyrie, L. (Eds.), Carbon Cycling in the Glacial Ocean: Constraints on the Ocean's Role in Global Change; Quantitative Approaches in Paleoceanography. NATO ASI Series I, Global Environmental Change, Springer, Berlin, pp. 521-537.

Dansgaard, W., Johnsen, S.J., Clausen, H.B., Dahljensen, D., Gundestrup, N.S., Hammer, C.U., Hvidberg, C.S., Steffensen, J.P., Sveinbjornsdottir, A.E., Jouzel, J., Bond, G., 1993. Evidence for general instability of past climate from a 250kyr ice-core record. Nature 364, 218-220.

den Dulk, M., Reichart, G.J., van Heyst, S., Zachariasse, W.J., Van der Zwaan, G.J., 2000. Benthic foraminifera as proxies of organic matter flux and bottom water oxygenation? A case history from the northern Arabian Sea. Palaeogeogr. Palaeoclimatol. Palaeoecol. 161, 337-359.

Deuser, W.D., Ross, E.H., Mlodzinska, Z.J., 1978. Evidence for and rate of denitrification in the Arabian Sea. Deep-Sea Res. I 25, 431-445.

Fairbanks, R.G., Wiebe, P.H., 1980. Foraminifera and chlorophyll maximum: Vertical distribution, seasonal succession and paleoceanographic significance. Science 209, 1524 1526.

Fairbanks, R.G., Sverdlove, M.S., Free, R., Wiebe, P.H., Be, A.W.H., 1982. Vertical distribution and isotopic fractionation of living planktonic foraminifera from the Panama Basin. Nature 298, 841-844.

Grootes, P.M., Stuiver, M., White, J.W.C., Johnsen, S., Jouzel, J., 1993. Comparison of oxygen-isotope records from the Gisp2 and Grip Greenland ice cores. Nature 366, 552 554.

Head, M.J., 1996. Modern dinoflagellate cysts and their biological affinities. In: Jansonius, J., McGregor, D.C. (Eds.), Palynology: Principles and Applications. American Association of Stratigraphic Palynologists, pp. 1197-1248.

Hopkins, J.A., McCarthy, F.M.G., 2002. Post-depositional palynomorph degradation in Quaternary shelf sediments: A laboratory experiment studying the effects of progressive oxidation. Palynology 26, 167-184.

Jannink, N.T., Zachariasse, W.J., Van der Zwaan, G.J., 1998 Living (Rose Bengal stained) benthic foraminifera from the Pakistan continental margin (northern Arabian Sea). DeepSea Res. I 45, 1483-1513.

Kabanova, J.G., 1968. Primary production in the north Indian Ocean. Okeanologiia 8, 270-278. 
Madhupratap, M., Kumar, S.P., Bhattathiri, P.M.A., Kumar, M.D., Raghukumar, S., Nair, K.K.C., Ramaiah, N., 1996. Mechanism of the biological response to winter cooling in the northeastern Arabian Sea. Nature 384, 549-552.

Olson, D.B., Hitchcock, G.L., Fine, R.A., Warren, B.A., 1993. Maintenance of the low-oxygen layer in the Central Arabian Sea. Deep-Sea Res. I 40, 673-685.

Pedersen, T.F., Shimmield, G.B., Price, N.B., 1992. Lack of enhanced preservation of organic-matter in sediments under the oxygen minimum on the Oman Margin. Geochim. Cosmochim. Acta 56, 545-551.

Prell, W.L., Hutson, W.H., Williams, D.F., Be, A.W.H., Geitzenauer, K., Molfino, B., 1980. Surface circulation of the Indian Ocean during the last glacial maximum, approximately 18,000 yr B.P.. Quat. Res. 14, 309-336.

Qasim, S.Z., 1982. Oceanography of the northern Arabian Sea. Deep-Sea Res. I 29, 1041-1068.

Reichart, G.J., den Dulk, M., Visser, H.J., van der Weijden, C.H., Zachariasse, W.J., 1997. A $225 \mathrm{kyr}$ record of dust supply, paleoproductivity and the oxygen minimum zone from the Murray Ridge (northern Arabian Sea). Palaeogeogr. Palaeoclimatol. Palaeoecol. 134, 149-169.

Reichart, G.J., Lourens, L.J., Zachariasse, W.J., 1998. Temporal variability in the northern Arabian Sea Oxygen Minimum Zone (OMZ) during the last 225,000 years. Paleoceanography 13, 607-621.

Reichart, G.J., Nortier, J., Versteegh, G.J.M., Zachariasse, W.J., 2002a. Periodical breakdown of the Arabian Sea oxygen minimum zone caused by deep convective mixing. In: Clift, P.D., Kroon, D., Craig, J., Gaedicke, C. (Eds.), The Tectonic and Climatic Evolution of the Arabian Sea Region. Geological Society of London Special Publication, London, pp. 407-420.

Reichart, G.J., Schenau, S.J., de Lange, G.J., Zachariasse, W.J., 2002b. Synchroneity of oxygen minimum zone intensity on the Oman and Pakistan Margins at sub-Milankovitch time scales. Mar. Geol. 185, 403-415.

Reichart, G.J., Brinkhuis, H., Huiskamp, F., Zachariasse, W.J., submitted. Hyperstratified conditions following glacial overturning events in the northern Arabian Sea. Paleoceanography.

Schulz, H., von Rad, U., Von Stackelberg, U., 1996. Laminated sediments from the oxygen-minimum zone of the northeastern Arabian Sea. In: Kemp, A.E.S. (Ed.), Paleoclimatology and Paleoceanography from Laminated Sediments. Geological Society Special Publication, pp. 185-207.

Schulz, H., von Rad, U., Erlenkeuser, H., 1998. Correlation between Arabian Sea and Greenland climate oscillations of the past 110,000 years. Nature 393, 54-57.

Shimmield, G.B., Mowbray, S.R., Weedon, G.P., 1990. A 350 ka history of the Indian Southwest Monsoon - Evidence from deep-sea cores, Northwest Arabian Sea. Trans. R. Soc. Edinb. Earth Sci. 81, 289-299.

Sinninghe Damste, J.S., Rijpstra, W.I.C., Reichart, G.-j., 2002. The influence of oxic degradation on the sedimentary bio- marker record, II. Evidence from Arabian Sea sediments. Geochim. Cosmochim. Acta 66, 2737-2754.

Slater, R.D., Kroopnick, P., 1984. Controls on dissolved oxygen distribution and organic carbon deposition in the Arabian Sea. In: Haq, Bilal, U., Milliman, John (Eds.), Marine Geology and Oceanography of Arabian Sea and Coastal Pakistan. Van Nostrand Reinhold, New York, pp. 305-313.

Smith, R.L., Bottero, J.S., 1977. On upwelling in the Arabian Sea. In: Angel, M. (Ed.), A Voyage of Discovery, George Deacon 70th Anniversary: Deep Sea Research. Pergamon Press, Oxford, pp. 291-304.

Swallow, J.C., 1984. Some aspects of the physical oceanography of the Indian Ocean. Deep-Sea Res. I 31, 639-650.

Traverse, A. (Ed.), 1994. Sedimentation of Organic Particles. Cambridge University Press, New York, 544 pp.

Van Bennekom, A.J., Hiehle, M.A., 1994. CTD operations and calibrations during legs D1, D2 and D3 of the Netherlands Indian Ocean Programme. In: van der Linden, W.J.M., van der Weijden, C.H. (Eds.), Geological Study of the Arabian Sea. National Museum of Natural History, Leiden, pp. 37-66.

van der Weijden, C.H., Reichart, G.J., Visser, H.J., 1999. Enhanced preservation of organic matter in sediments deposited within the oxygen minimum zone in the northeastern Arabian Sea. Deep-Sea Res. I 46, 807-830.

van Os, B.J.H., Middelburg, J.J., Delange, G.J., 1991. Possible diagenetic mobilization of barium in sapropelic sediment from the Eastern Mediterranean. Mar. Geol. 100, 125-136.

Versteegh, G.J.M., Zonneveld, K.A.F., 2002. Use of selective degradation to separate preservation from productivity. Geology 30, 615-618.

Williams, G.L., Lentin, J.K., Fensome, R.A., 1998. The Lentin and Williams index of fossil dinoflagellates, 1998 edition. Am. Assoc. Strat. Palynol. Contr. 34, AASP Foundation, 817 pp.

Wyrtki, K., 1973. Physical oceanography of the Indian Ocean. In: Zeitschel, B. (Ed.), The Biology of the Indian Ocean. Springer, Berlin, pp. 18-36.

You, Y., Tomczak, M., 1993. Thermocline circulation and ventilation in the Indian Ocean derived from water mass analysis. Deep-Sea Res. I 40, 13-56.

Zonneveld, K.A.F., 1996. Palaeoclimatic and Palaeo-Ecologic Changes in the Eastern Mediterranean and Arabian Sea Regions during the Last Deglaciation: A Palynological Approach to Land-Sea Correlation. LPP contributions 3, LPP Foundation, Utrecht, $1999 \mathrm{pp}$.

Zonneveld, K.A.F., Versteegh, G.J.M., de Lange, G.J., 1997. Preservation of organic-walled dinoflagellate cysts in different oxygen regimes: A 10,000 year natural experiment. Mar. Micropaleontol. 29, 393-405.

Zonneveld, K.A.F., Versteegh, G.J.M., de Lange, G.J., 2001. Palaeoproductivity and post-depositional aerobic organic matter decay reflected by dinoflagellate cyst assemblages of the Eastern Mediterranean S1 sapropel. Mar. Geol. 172, 181-195. 